\title{
KOMBINASI METODE ABC DAN MMSL DALAM PENGENDALIAN STOK OBAT
}

\author{
Siti Hartinah, Kusrini, Mei P Kurniawan \\ Magister Teknik Informatika, Fakultas Ilmu Komputer, Universitas Amikom Yogyakarta \\ J1. Ring Road Utara, Ngiringin, Condong Catur, Kec. Depok, Kab. Sleman Yogyakarta 55281 \\ E-mail: siti.1148@students.amikom.ac.id, kusrinieamikom.ac.id \\ meikurniawaneamikom.ac.id
}

\begin{abstract}
In hospitals, problems often occur in the management of drug supplies with the condition that the drug runs out due to spending in one year $30 \%$ for the investment cost of drugs. In overcoming this problem, the hospital should have good drug data processing, processing can be done by doing good management. The author will use the ABC method combined with MMSL. ABC functions in grouping $\mathrm{A}, \mathrm{B}$ and $\mathrm{C}$ and is combined with MMSL in calculating Maximum Stock and Minimum stock. From this study, it was found that using the ABC method of drug analysis was grouped based on drug use into three groups, namely group A with a percentage of $21.90 \%$, group B with a percentage of $32.25 \%$ and group $C$ with a percentage of $45.85 \%$. For the results of MMSL, namely combining several variables in the ABC to MMSL algorithm. The results of the MMSL entered into the drug stock control process that the optimal prediction was $17.15 \%$ MAPE compared to the MAPE investment value $19.05 \%$ and the MAPE lead time $18.14 \%$.
\end{abstract}

Keywords - MMSL, Classification, Prediction, ABC Analysis

\begin{abstract}
Abstrak - Pada rumah sakit sering terjadi permasalahan pada pengelolaan persedian obat dengan kondisi obat habis disebabkan oleh pengeluaran dalam satu tahun $30 \%$ untuk biaya investasi obat. Dalam mengatasi permasalahan ini rumah sakit seharunya mempunyai pengolahan data obat yang baik, cara pengolahan bisa dengan melakukan management yang baik. Penelitian ini menggunakan metode ABC dikombinasikan dengan MMSL. ABC berfungsi dalam pengelompokan A,B dan C serta dikombinasikan dengan MMSL dalam menghitung Maximum Stock dan Minimum stock. Dari penelitian ini mandapatkan hasil bahwa dengan menggunakan metode ABC analisis obat dikelompokan berdasarkan pemakaian obat menjadi tiga kelompok yaitu kelompok A dengan persentase $21.90 \%$, kelompok B dengan persentase $32.25 \%$ dan kelompok C dengan persentase 45.85\%. Untuk hasil dari MMSL yakni mengkombinasikan beberapa variabel pada algoritma ABC ke MMSL. Hasil dari MMSL masuk kedalam proses pengendalian stock obat bahwa prediksi yang optimal yakni MAPE $17.15 \%$ dibandingkan dengan nilai investasi MAPE $19.05 \%$ dan Lead time MAPE $18.14 \%$.
\end{abstract}

Kata Kunci - MMSL, Klasifikasi, Prediksi , ABC Analisis.

\section{PENDAHULUAN}

Pada rumah sakit terdapat devisi farmasi yang menyediakan berbagai macam obat-obatan. Obat merupakan bahan penting untuk proses pelayanan klinik kesahatan salah satunya pada rumah sakit. Manajemen obat dan pengelolaan obat merupakan salah satu indikator mutu pelayanan dalam farmasi. Untuk proses manajemen obat dimulai dari seleksi, kontribusi, dan pengaadan terakhir obat. Ini merupakan penggunaan standar manajemen obat yang baik, bila ditambah dengan sebuah metode atau rumus algoritma perhitungan barang dapat menjamin stock obat pada unit-unitnya. Proses manajemen dan pengeolaan obat dipengaruhi oleh faktor diantarannya, fasilitas kesehatan, tenaga kerja atau sumber daya manusia, adminsistrasi, harga, serta sistem informasi. Untuk manajemen obat yang mempuni tetapi berdampak dengan meningkatnya layanan obat, namun juga berdampak dengan tingkat kepuasan pelanggan terhadap pelayanan subtansi tersebut. [1].
Pada waktu-waktu tertentu dirumah sakit menggunakan biaya $37 \%$ dari total biaya untuk investasi obat saja. 37\% merupakan biaya yang besar, akibatnya sumber daya manusia/personil memerlukan pengelolaan serta manajemen obat yang baik serta maksimal, jika tidak permasalahan ini berakibat pada pendapatan rumah sakit/klinik [2].

Pada bagian farmasi sebaiknya melakukan manajemen obat dengan jumlah data ribuan jenis dalam perkembangan dari rumah sakit atau klinik untuk setiap transaksi [3].

Masalah yang terjadi pada manajemen dan pengelolaan untuk persedian obat yakni terjadinya stock out obat, namun ada konsumen yang ingin membeli. Permasalahan tersebut sering tarjadi dikarenakan unit farmasi kurang tepat dalam memanajamen pengendalian persedian obat [4]

Pada review yang dilakukan penelitian sebelumnya oleh Tutik maryana pada tahun 2019 mendapat hasil bahwa klasifikasi menggunakan ABC Analysis mendapatkan hasil yang akurat serta 
persentase yang cukup. Dimana obat dibagi menjadi 3 bagian yakni kelompok A persentase 22,96\% kelompok B persentase $33,11 \%$ dan $\mathrm{C}$ persentase 43,94\% dengan kasus klasifikasi obat [5]. Dilain penelitian yang dilakukan oleh Rathanaksambath Ly dan Marrokot Raweewan dengan judul penelitian Flexible ABC Inventory Clasification menjelaskan hasil dalam penggolongan berdasarkan penjualan untuk periode tertentu, akan memiliki hasil penggolongan yang dapat maksimalkan laba di kondisi anggaran pasokan seadanya dan tempat penyimpanan yang terbatas [6].

Dipenelitian berikutnya yakni pengendalian persediaan dengan minimum-maxium stock level (MMSL). Pada penelitian tersebutn menggunakan variable suplay fokus, nilai investasi, lead time, ratarata pengguna perhari. Hasil dari penelitian tersebut adalah memberikan dampak positif dari efesisensi persedian obat yakni dengan adanya penurunan angka kejadian dari 8 kali intervensi menjadi 2 kali intervensi. Dari penelitian tersebut bisa mendapatkan informasi jika MMSL bisa digunakan pada pegendalian stock obat [7].

Untuk kasus dirumah sakit yang dijadikan objek dalam penelitan merupakan proses pengendalian prediksi dalam penngeluaran obat dalam transaksi penjualan obat dalam mengendalikan stok obat yang safety ditiap bulan oleh karyawan pengadaan obat yaitu melakukan pengambilan data penjualan dibulan ini lalu dirata-rata untuk penjualan setiap bulan kedepannya akan mendapatkan rata-rata penjualan perhari. Data tersebut nantinya akan menjadi dasar dalam perhitungan perkiraan penjualan pada bulan berikutnya. Berikutnya berfungsi menjadi patokan dasar dalam perhitungan pengadaan obat. Dari cara yang digunakan oleh karyawan pengadaan tesebut tercatat mulai bulan Agustus 2019 - Juni 2020 diperoleh data yakni 11 bulan tersebut memiliki 7 bulan pada rumah sakit sering terjadi obat habis dan obat kelebihan stock obat. Akibatnya bisa memperlambat pelayanan serta anggaran kas obat [8].

Dalam rangka mengurangi resiko dari permasalahan rumah sakit tersebut, maka bisa menggunakan metode klasifikasi [9]. Klasifikasi dapat dilakukan dengan cara menggunakan metode ABC dengan menambahkan normalisasi didalamnya.

Penulis memilih metode MMSL karena metode tersebut mampu mengendaliakan persediaan stock obat dan dikombinasikan dengan metode ABC Analysis untuk melihat pengelompokan obat sesuai dengan nilai kebutuhan kelompok barang, pada algoritma ini obat dikelompokan ke tiga bagian yakni kelas A, B dan C berdasarkan variable nilai penjualan, pemakaian obat dan lead time. Dari sini rumah sakit akan dapat melihat tingkat pengunakan obat tersebut.

\section{METODE PENELITIAN}

\section{A. Pengumpulan Data}

Dalam pengumpulan data penulis mengambil data primer [9]. Dimana data diambil dari sumber data pertama yakni melalui aplikasi yang diakses pada rumah sakit tersebut. Data tersebut dalam bentuk .dmp. Ini diambil dari database pada rumah sakit. Adapun alur dalam pengambilan data bisa dilihat pada gambar 1 .

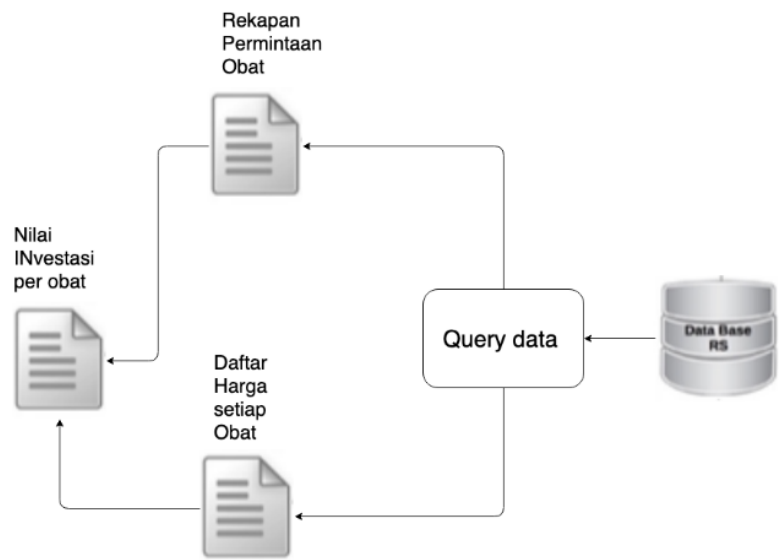

Gambar 1. Alur Proses Pengambilan Data

\section{B. Analisis Data}

Analisa data di penelitian ini berisi analisi kuantitatif. Dimana prosedur pengelompokan obat dijalankan kedalam keluaran pengelompokan obat dengan hasil pembagian obat menjadi kelompok A, B dan C. Selanjutnya yakni melakukan prediksi obat menggunakan MMSL. Variabel yang digunakan pada proses prediksi yaitu obat masuk (Obat yang baru masuk dari supplier obat ke rumah sakit), obat keluar(Obat yang keluar dan dipakai dari rumah sakit atas resep dokter atau pihak apoteker untuk pasien), kesediaan obat, lead time (merupakan tenggang waktu yang dibutuhkan untuk mendapatkan persediaan. Dihitung mulai hari pemesanan barang hingga hari barang datang), stock maximum dan minimum dan safety stock. Di proses prediksi obat dilakukan tiga uji Skenario. Diantaranya, berdasarkan pemakain obat, nilai investasi obat, jangka waktu pembuatan obat. Adapun alur analisa yang digunakan adalah sebagai berikut.

a. Analisa untuk proses pengelompokan terlihat pada gambar 2 :

Rekapan
Data
Obat $\rightarrow \begin{gathered}\text { Daftar } \\ \text { Harga } \\ \text { Obat }\end{gathered} \rightarrow \begin{gathered}\text { Data } \\ \text { Investasi } \\ \text { Perobat }\end{gathered} \rightarrow \begin{gathered}\text { Data } \\ \text { Jangka Waktu } \\ \text { Pembuatan Obat }\end{gathered} \rightarrow \begin{gathered}\text { Proses } \\ \text { Klasifikasi }\end{gathered} \rightarrow \begin{gathered}\text { Hasil } \\ \text { Klasifikasi }\end{gathered}$

Gambar 2. Pengelompokan dengan ABC Analisis

Dari Gambar 2 Pengelompokan dengan ABC diatas menjelaskan jika proses pengelompokan obat berdasarkan dari rekap harga obat dan data obat. Kedua variable digunakan dalam pancarian nilai 
investasi per obat. Data diurutkan berdasarkan jenjang tertinggi sampai jenjang terendah dari nilai investasi dan hitung nilai investasi komulatif serta presentasi komulatifnya. Tahapan akhir yakni pengelompokan obat mejadi A,B dan C.

b. Analisa untuk proses prediksi terlihat pada gambar 3 .

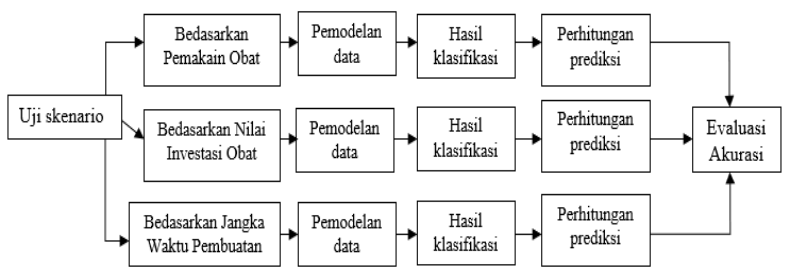

Gambar 3. Metode Pengolahan Data Untuk Prediksi

Dari gambar diatas dapat diambil penjelasan bahwa proses prediksi dilakukan dengan tiga skenario, yaitu berdasarkan pemakain obat, nilai investasi obat, jangka waktu pembuatan obat. Berikutnya melakukan pemodelan data dari tiap-tiap parameter. Selanjutnya ke tahap hasil klasifikasi, dari klasifikasi melakukan perhitungan prediksi dengan menghitung minimal dan maximal dari pemakaian obat, investasi obat, jangka waktu pembuatan, dari parameter ini nantinya akan terlihat untuk hasil evaluasi akurasi dari pengendalian stok obat.

\section{Alur Penelitian.}

Adapun Alur penelitian yang digunakan yakni seperti berikut:

1. Identifikasi masalah, pada proses identifikasi masalah pemilihan serta melakukan perumusan masalah untuk mengerucutkan permasalahan yang akan diteliti serta definisi operasional dari masalah yang dihadapi.

2. Menentukan tujuan dan batasan masalah, berisi langkah dan maksud dari hasil penelitian serta membatasi ruang lingkup penelitian.

3. Identifikasi kebutuhan data, berisi langkah dalam pencarian data yang digunakan pada penenlitian seperti sumber data, penentuan objek penelitian serta variasi dataset yang dibutuhkan serta digunakan.

4. Analisis data, berisi penggunaan metode algoritma/metode yang cocok digunakan dalam penelitian terdapat beberapa kombinasi algoritma serta parameter yang dipakai.

5. Klasifikasi Obat, berisi tentang prosedur pengelompokan dengan metode ABC Analisys akan menghasilkan pembagian kelompok obat menjadi 3 kelompok. Pengelompokan obat berdasarkan variable yang sudah ditetapkan oleh peneliti.

6. Prediksi pada MMSL, prosedur disini yakni melakuakn proses perhitungan untuk pengendalian stock obat menggunakan metode
MMSL yang dimana obat stock minimum dan maximum obat di lakukan secara terpisah.

7. Uji skenario, menjelaskan tentang percobaan yang dilakukan peneliti berdasarkan pemakaian obat, nilai investasi obat dan berdasarkan jangka pembuatan obat (leadtime).

8. Proses Akurasi, proses akurasi menggunakan Mean Absolute Presentage Error (MAPE) dilakukan untuk melihat berapa tingkat keakuratan dari prediksi obat menggunakan metode ABC dan MMSL. Karna dari rumah sakit untuk pengendalian stock obat masih manual, maka peneliti melakukan uji coba langusung setiap bulan.

9. Kesimpulan dan evaluasi, berisi tentang informsi hasil akhir dari penelitian yang telah dilakukan serta bagaimana evaluasi yang sebaiknya dilakukan

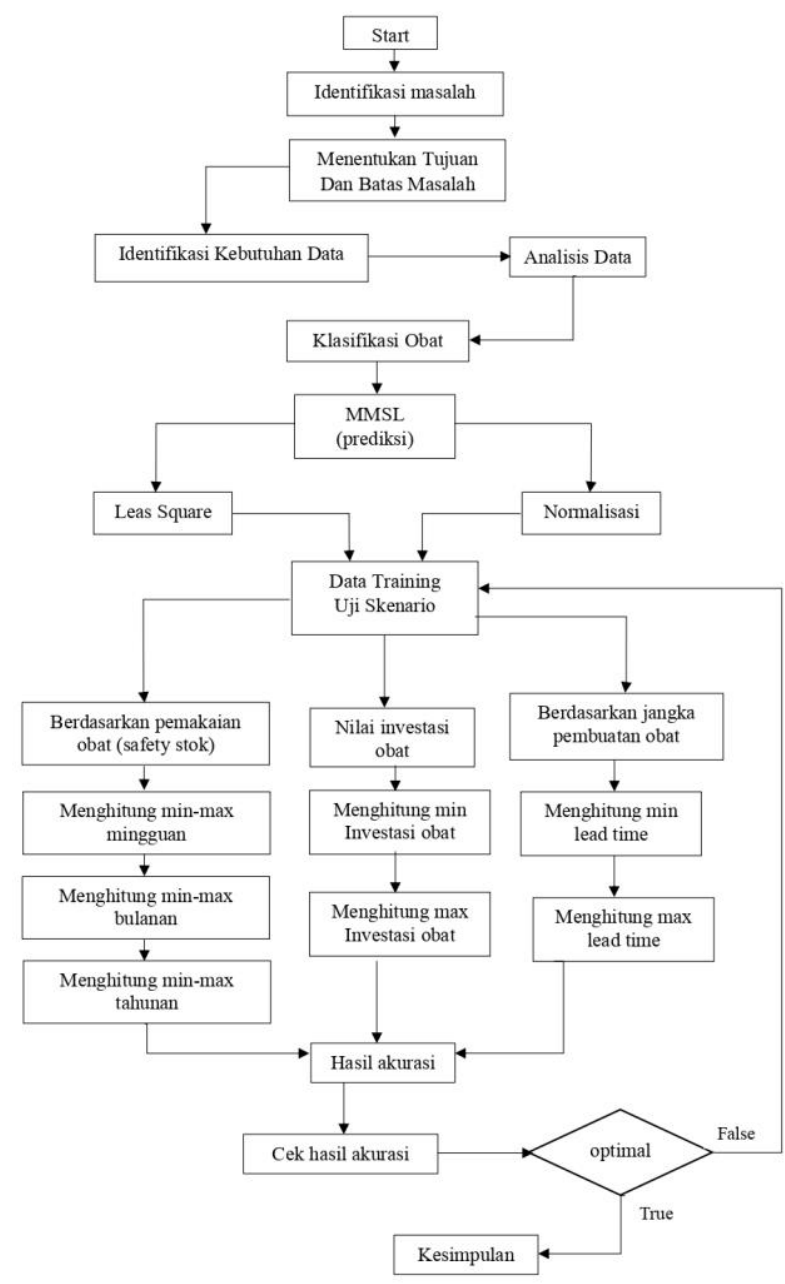

Gambar 4. Alur Penelitian.

\section{HASIL DAN PEMBAHASAN}

A. Klasifikasi ABC analisis.

Proses klasifikasi menggunakan metode ABC analisys yang dilakukan penulis mendapatkan hasil 
yakni dengan mengelompokan menjadi tiga kelompok yakni kelompok A, B dan C[12]. Penulis mendapatkan hasil percobaan sesuai dengan tabel 1 berikut ini:

Tabel 1. Hasil Klasifikasi ABC Analisys

\begin{tabular}{|l|l|l|l|l|}
\hline $\begin{array}{l}\text { Jenis } \\
\text { Kel. }\end{array}$ & QTY & $\begin{array}{l}\text { Presentase } \\
\text { Jumlah } \\
\text { Item }\end{array}$ & $\begin{array}{l}\text { Total Investasi } \\
\text { (dalam Rp) }\end{array}$ & $\begin{array}{l}\text { Presenta } \\
\text { se Total } \\
\text { Investasi }\end{array}$ \\
\hline A & 270 & $21,90 \%$ & 5.913 .800 .351 & $74,81 \%$ \\
\hline B & 387 & $32,25 \%$ & 1.003 .850 .105 & $13,43 \%$ \\
\hline C & 523 & $45,85 \%$ & 801.840 .257 & $11,76 \%$ \\
\hline $\begin{array}{l}\text { Jumla } \\
\text { h }\end{array}$ & 1196 & $100 \%$ & 7.719 .490 .713 & $100 \%$ \\
\hline
\end{tabular}

\section{Proses Prediksi MMSL menggunakan Data Hasil} Klasifikasi Berdasarkan Pemakaian Obat.

Proses prediksi yang penulis lakukan menggunakan data sample 6 obat dengan berdasarkan pemakainan obat yang sering digunakan Klasifikasi A. uji prediksi dilakukan menggunakan metode fold cross falidation. Penulis yang digunakan untuk paramater adalah $\mathrm{C}=1, \mathrm{C}=10, \mathrm{C}=100$ dan $\varepsilon=0.1$. untuk hasil uji 6 item tersebut dapat dilihat pada tabel 2 .

Tabel 2. Hasil MMSL dalam pemakaian obat

\begin{tabular}{|l|l|l|l|}
\hline \multirow{2}{*}{ Nama Obat } & \multicolumn{3}{|c|}{ MAPE (dalam \%) } \\
\cline { 2 - 4 } & $\mathrm{C}=1$ & $\mathrm{C}=10$ & $\mathrm{C}=100$ \\
\hline Daryant Tulle & 47,67 & 40,75 & 39,23 \\
\hline Fleet Phosphosoda & 39,87 & 29,96 & 30,29 \\
\hline Glikuidon 30 Mg & 56,87 & 49,76 & 65,78 \\
\hline Metroklopramid Tablet & 38,21 & 39,29 & 30,95 \\
\hline Fondazen Tab & 35,98 & 33,83 & 31,90 \\
\hline
\end{tabular}

Mape yang dihasilkan untuk penelitian yang dikerjakan oleh penulis tiap masing-masing obat memiliki rata 35\%. Sedangkan untuk uji hasil Akurasi dari pemakain obat adalah sebagai berikut:

Tabel 3. Hasil Pengujian

\begin{tabular}{|c|c|c|c|}
\hline \multirow{2}{*}{ UJI KE } & $\begin{array}{c}\text { MAPE }(\%) \\
\begin{array}{c}\mathrm{C}=1 \text { dan } \\
=0.1\end{array}\end{array}$ & $\begin{array}{c}\mathrm{C}=10 \text { dan } \\
\square=0.1\end{array}$ & $\begin{array}{c}\mathrm{C}=100 \\
\text { dan } \\
=0.1\end{array}$ \\
\hline 1 & 15,87 & 15,85 & 16,33 \\
\hline 2 & 16,89 & 13,88 & 14,08 \\
\hline 3 & 20,13 & 16,65 & 15,03 \\
\hline 4 & 27,68 & 23,85 & 22,88 \\
\hline 5 & 16,42 & 17,55 & 18,03 \\
\hline Rata-rata & 19,39 & 17,55 & 17,27 \\
\hline
\end{tabular}

\section{Proses Uji Skenario MMSL menggunakan Data}

Hasil Klasifikasi Nilai Investasi Obat

Untuk proses menggunakan Minimum dan Maximum Stock Level penulis menggunakan satu sampel data obat yakni FONDAZEN TAB, obat tersebut memperlihatkan untuk nilai investasi obat min dan mas obat bisa dilihat pada table 3 .
Tabel 4. Hasil Max dan Min dari Stock Level

\begin{tabular}{|l|l|l|}
\hline Min & Max & Nilai \\
\hline 207 & 470.5 & 787 \\
\hline
\end{tabular}

Penulis melakukan uji coba menggunakan KFold Cross falidation dengan nilai $\mathrm{K}=5$ sehingga terbagi menjadi 5 blok serta memiliki panjang data yang sama.

Tabel 5. Hasil Pengujian

\begin{tabular}{|c|c|c|c|}
\hline \multirow{2}{*}{ UJI KE } & \multicolumn{3}{|c|}{ MAPE (\%) } \\
\cline { 2 - 4 } & $\begin{array}{c}\mathrm{C}=1 \text { dan } \\
=0.1\end{array}$ & $\begin{array}{c}\mathrm{C}=10 \text { dan } \\
\square=0.1\end{array}$ & $\begin{array}{c}\mathrm{C}=100 \\
\text { dan } \\
=0.1\end{array}$ \\
\hline 1 & 15,86 & 15,77 & 16,33 \\
\hline 2 & 16,89 & 14,7 & 14,08 \\
\hline 3 & 20,0 & 16,75 & 16,61 \\
\hline 4 & 28,68 & 22,62 & 22,88 \\
\hline 5 & 17,72 & 17,73 & 18,03 \\
\hline Rata-rata & 19,83 & 17,51 & 17,59 \\
\hline
\end{tabular}

Berdasarkan table 4 hasil pengujian dengan MAPE terendah adalah 17,51 dengan $\mathrm{C}=10$ dan $\square=$ 0,1 . Hasil tersebut menunjukan bahwa lebih optimal dari pada peramalan MMSL tanpa perpocessing data.

\section{Proses Uji Skenario MMSL menggunakan Data}

Hasil Klasifikasi Lead Time

Proses prediksi berdasarkan data Lead Time penulis menggunakan data obat FONDAZEN TAB, obat tersebut menunjukan bahwa pola data leadtime (jangka waktu pembuatan obat) dapat dilihat pada table 5 berikut:

Tabel 6. Hasil MMSL menggunakan Lead Time

\begin{tabular}{|l|l|l|l|l|l|}
\hline Min & Max & Median & Mean & $3^{\text {rd }}$ Qu & Max \\
\hline 207 & 470.5 & 787 & 586.7 & 675 & 953 \\
\hline
\end{tabular}

Penulis melakukan uji coba menggunakan KFold Cross falidation dengan nilai $\mathrm{K}=5$ sehingga terbagi menjadi 5 blok serta memiliki panjang data yang sama.

Tabel 7. Hasil Pengujian

\begin{tabular}{|c|c|c|c|}
\hline \multirow{2}{*}{ UJI KE } & $\begin{array}{c}\mathrm{3}=1 \text { dan } \\
\square\end{array}$ & $\begin{array}{c}\mathrm{C}=10 \text { dan } \\
\square=0.1\end{array}$ & $\begin{array}{c}\mathrm{C}=100 \\
\text { dan } \\
=0.1\end{array}$ \\
\hline 1 & 15,86 & 15,69 & 15,65 \\
\hline 2 & 15,56 & 15,75 & 15,66 \\
\hline 3 & 19,22 & 18,68 & 18,63 \\
\hline 4 & 26,64 & 25,89 & 26,75 \\
\hline 5 & 17,42 & 17,43 & 17,44 \\
\hline Rata-rata & 18,09 & 18,69 & 18,83 \\
\hline
\end{tabular}

Pada hasil uji tabel 7 Mape terkecil adalah Mape $18.09 \%$. hasil tersebut adalah hasil optimal 
dari pada prediksi tanpa menggunakan pengelompokan terlebih dahulu.

\section{Grafik Perbandingan}

Adapun hasil grafik perbandingan dari hasil penelitian yang dilakukan, maka dapat dilihan pada grafik perbandingan sebagai berikut:

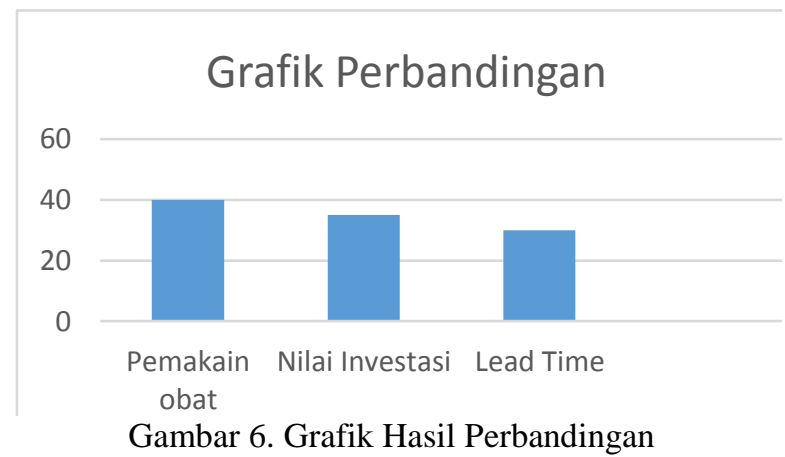

\section{KESIMPULAN}

Untuk hasil penelitian dalam kasus pengendalian stock obat dengan menggunakan MMSL yakni mendapatkan hasil bahwa bila menggunakan variable pemakaian obat dengan dikelompokan terlebih dahulu lalu di masukan kedalam MMSL maka akan mendapatkan prediksi yang optimal yaitu MAPE 17,55\%. Dimana jika menggunakan factor berdasarkan pemakaian obat mengurangi tingkat stock out obat sebesar $45 \%$. dibandingkan dengan varibel lain yakni nilai investasi mape $19,05 \%$ sedangkan berdasarkan nilai investasi obat berpengaruh sebesar $30 \%$ dalam stock out obat. dan MAPE lead time $18,14 \%$ untuk stock out obat sebesar $25 \%$.

\section{DAFTAR PUSTAKA}

[1] B. Santoso, Data Mining Teknik Pemanfaatan Data untuk Keperluan Bisnis. Yogyakarta: Graha Ilmu, 2007.

[2] F. Binsar and T. Mauritsius, "Drug stock optimization based on consumption patterns for hospital formulary using deep learning approach," Int. J. Adv. Trends Comput. Sci. Eng., vol. 9, no. 3, pp. 2689-2697, 2020, doi: 10.30534/ijatcse/2020/31932020.

[3] B. Santoso, Data Mining Teknik Pemanfaatan Data untuk keperluan bisnis. Yogyakarta: Graha Ilmu.

[4] M. Y. Martei et al., "Impact of essential medicine stock outs on cancer therapy delivery in a resource-limited setting," J. Glob. Oncol., vol. 2019, no. 5, 2019, doi: 10.1200/JGO.18.00230.

[5] T. Maryana, K. Kusrini, and H. Al Fatta, "Analisis Perbandingan Predisksi Obat Dengan Menggunakan Metode Abc Analisys Dan Svr Pada Aplikasi 'Morbis,"” J. Teknol. Inf., vol. 3, no. 2, p. 174, 2019, doi: 10.36294/jurti.v3i2.1016.

[6] R. Ly and M. Raweewan, "Flexible ABC Inventory Classification," KnE Life Sci., vol. 4, no. 2 , p. 228, 2018, doi: 10.18502/kls.v4i2.1676.

[7] T. R. Indarti, S. Satibi, and E. Yuniarti, "Pengendalian Persediaan Obat dengan Minimum-Maximum Stock Level di Instalasi Farmasi RSUP Dr. Sardjito Yogyakarta," J. Manaj. DAN PELAYANAN Farm. (Journal Manag. Pharm. Pract., vol. 9, no. 3, p. 192, 2019, doi: 10.22146/jmpf.45295.

[8] P. D. Cerna and T. J. Abdulahi, "Prediction of Anti-Retroviral Drug Consumption for HIV Patient in Hospital Pharmacy using Data Mining Technique," Int. J. Inf. Technol. Comput. Sci., vol. 8, no. 2, pp. 52-59, 2016, doi: 10.5815/ijitcs.2016.02.07.

[9] D. Suwardiyanto, M. Nur Shodiq, D. Hidayat Kusuma, and T. Oktalita Sari, "Sistem Prediksi Kebutuhan Obat di Puskesmas Menggunakan Metode Least Square," J. Inform. J. Pengemb. IT, vol. 4, no. 1, pp. 75-80, 2019, doi: 10.30591/jpit.v4i1.1085. 